\begin{tabular}{c} 
JURNAI R RS'II \\
IAll $\begin{array}{l}\text { (Rekayasa Sistem dan Teknologi Informasi) } \\
\text { Vol.4No.6(2020) } 1157-1164\end{array}$ \\
\hline
\end{tabular}

\title{
Advanced Encryption Standard (AES) 128 Bit untuk Keamanan Data Internet of Things (IoT) Tanaman Hidroponik
}

\author{
Roiya Ravida ${ }^{1}$, Heru Agus Santoso ${ }^{2}$ \\ ${ }^{1,2}$ Program Studi Teknik Informatika, Fakultas Ilmu Komputer, Universitas Dian Nuswantoro \\ ${ }^{1}$ roiyaravida36@ gmail.com, ${ }^{2}$ heru.agus.santoso@dsn.dinus.ac.id*
}

\begin{abstract}
It is easier to grow vegetables using hydroponic techniques in the era of globalization. In hydroponic techniques, the need for certain plants to grow is very important to note. Manually, controlling and checking conditions is difficult to measure, so a system that can check plant needs is needed. Internet of Things (IoT) is known to be used to manage hydroponic plants. The drawback of IoT is the use of the system in general, resulting in confusion in the process of detecting plant needs. In IoT, it is important to implement system security with the aim of limiting interested users. In this study, the IoT security process was carried out using cryptographic techniques, namely the 128-bit Advanced Encryption Standard (AES) algorithm. This algorithm was chosen because it has a safer encryption result compared to similar symmetrical algorithms such as Blowfish, Caesar cipher and faster than the Data Encryption Standard (DES). Cryptography is used in securing the input data for plant needs designed using the ESP 8266 version of the Arduino Uno SoC microcontroller. Several criteria for selected plant needs include Total Dissolve Solid (TDS), Potential Hydrogen (PH), temperature, and distance that have been captured through Sensors and stored in the database before cryptography processing. Experimental results to prove data security in the IoT system have been done by analyzing plaintext and ciphertext, calculating the Avalanche Effect (AE), entropy and Bit Error Ratio (BER) values. AE obtained $58.01 \%$ as the highest yield, the highest entropy was 6.3566 while all data resulted in BER= 0 . Based on the results obtained, it can be concluded that 128-bit Advanced Encryption Standard (AES) cryptography on IoT systems is good and according to standards.
\end{abstract}

Keywords: Advanced Encryption Standard, Internet of Things, Hydroponic Plants, Avalanche Effect, Entropy

\begin{abstract}
Abstrak
Model bercocok tanam sayuran lebih mudah menggunakan teknik hidroponik di era globalisasi. Dalam teknik hidroponik, kebutuhan tanaman akan zat tertentu untuk tumbuh sangat penting untuk diperhatikan. Secara manual, pengaturan dan pengecekan kondisi menjadi hal yang sulit diukur sehingga diperlukan sistem yang dapat mengecek kebutuhan tanaman. Internet of Things (IoT) dikenal dapat digunakan untuk melakukan pengelolaan terhadap tanaman hidroponik. Kekurangan IoT yaitu penggunaan sistem secara umum sehingga mengakibatkan kerancuan dalam proses deteksi kebutuhan tanaman. Dalam IoT penting diterapkan keamanan sistem dengan tujuan membatasi user yang berkepentingan. Pada penelitian ini, proses pengamanan IoT dilakukan menggunakan teknik kriptografi yaitu algoritma Advanced Encryption Standard (AES) 128 bit. Algoritma ini dipilih karena mempunyai hasil enkripsi lebih aman dibanding algoritma simetris sejenis misalnya Blowfish, Caesar cipher serta lebih cepat dibanding Data Encryption Standard (DES). Kriptografi digunakan dalam mengamankan data kebutuhan tanaman yang dirancang menggunakan mikrokontroler Arduino Uno SoC versi ESP 8266. Beberapa kriteria kebutuhan tanaman yang di pilih antara lain Total Dissolve Solid (TDS), Potential Hydrogen (PH), temperatur, dan jarak telah ditangkap melalui Sensor2 dan disimpan dalam database sebelum diolah dengan kriptografi. Hasil percobaan untuk membuktikan keamanan data dalam sistem IoT telah dilakukan dengan menganalisis teks dan cipher-text, menghitung nilai Avalanche Effect (AE), entropi dan Bit Error Ratio (BER). AE memperoleh 58,01\% sebagai hasil tertinggi, entropi tertinggi 6,3566, sedangkan semua data menghasilkan BER $=0$. Berdasarkan hasil yang telah diperoleh, dapat disimpulkan bahwa kriptografi Advanced Encryption Standard (AES) 128 bit pada sistem IoT sudah baik dan sesuai standard.
\end{abstract}

Kata kunci: Advanced Encryption Standard, Internet of Things, tanaman hidroponik, Avalanche Effect, entropi

Diterima Redaksi : 17-09-2020 | Selesai Revisi : 03-11-2020 | Diterbitkan Online : 20-12-2020 


\section{Pendahuluan}

Secara umum, keuntungan penggunaan IoT adalah peningkatan customer engagement, optimasi teknologi, minimalisasi pemborosan, serta enchanced data collection. Namun keamanan IoT sangat lemah, seperti pada kejadian yang menimpa perusahaan Cina Orvibo yang menjalankan smarthome platform. Perusahaan tersebut menawarkan smarthome untuk mempermudah aktivitas user di dalam rumah. Data yang disimpan tidak diberikan pengamanan apapun sehingga sekelompok peretas bernama "hacktivis" dapat membaca dan mengakibatkan pelanggaran keamanan. Dengan demikian keamanan data sangat penting karena menyangkut privasi pengguna smarthome [1]. Kemananan kunci sistem IoT merupakan hal mendasar dalam pertukaran informasi [2]. Model keamanan data dapat dilakukan menggunakan teknik penyandian data, dalam bentuk enkripsi dan dekripsi [3]. Hanya pengirim dan penerima sajalah yang dapat mengetahui kunci dari proses penyandian [4]. Teknik penyandian ini dikenal dengan kriptografi.

Berdasarkan kunci yang digunakan, kriptografi terbagi menjadi dua yaitu simetris dan asimetris [5]. Kriptografi simetris menggunakan kunci yang sama antara proses enkripsi dan dekripsi sedangkan asimetris menggunakan kunci yang berbeda. Kunci asimetris dinilai lebih aman dibanding simetris namun algoritma yang dapat digunakan masih terbatas dan membutuhkan waktu operasi lebih lama. Kriptografi simetris dapat dikatakan aman apabila kunci yang digunakan merupakan kombinasi angka dan huruf yang rumit. Semakin panjang kunci yang digunakan tentu dapat meningkatkan keamanan. Salah satu algoritma simetris dengan operasi yang cepat adalah Advanced Encryption Standard (AES) [6].

AES lebih cepat dibanding Data Encryption Standard (DES) dalam proses enkripsi-dekripsi [8], hal ini diperoleh dari 10 putaran kunci sebelum proses enkripsi. Secara realtime, AES juga terbukti dapat mengirim pesan melalui sistem [9]. Menurut [10], AES 128-bit dapat mengenkripsi file dokumen dengan mengkonversinya menjadi kode Standard Code for Information Interchange (ASCII) selama 10 putaran sehingga data yang dihasilkan akan sulit untuk dikonversi ke aslinya apabila tidak menggunakan kunci asli. Hal ini seperti yang terjadi pada pengamanan data untuk smarthome menggunakan AES, diketahui bahwa protokol jaringan harus tahan terhadap serangan [11]. Berdasarkan [12], AES telah terbukti aman untuk diimplementasikan ke dalam jaringan karena integritas data, kerahasiaan dan efisiensi tetap terjaga. Menurut [13], AES terbukti mempunyai waktu enkripsi dan dekripsi lebih cepat di banding Blowfish. File teks AES hasil dekripsi dan file asli tidak mengalami perubahan [14], dan apabila dibandingkan dengan Caesar cipher maka AES lebih aman setelah dilakukan pengujian menggunakan teknik brute force.
Pada penelitian yang dilakukan oleh [15], proses pengamanan sistem IoT telah dilakukan menggunakan DES dan Data Encryption Standard Lightweight (DESL). Tetapi dalam peneltian ini hanya dihasilkan perbandingan waktu enkripsi dan dekripsi saja. Penelitian yang dilakukan oleh [16] menjelaskan mengenai perbandingan antara AES dan Blowfish pada kriteria waktu enkripsi, waktu dekripsi dan alokasi penggunaan memori. AES lebih cepat dalam melakukan enkripsi plainteks dibandingkan dengan Blowfish. Penelitian lain yang dilakukan oleh [17], melalui modifikasi S-Box dan ekspansi kunci AES telah berhasil menekan kebutuhan daya dalam proses integrasi sistem IoT.

Berdasarkan kebutuhan model cocok tanam hidroponik yang lebih mudah menggunakan IoT, dan kebutuhan akan keamanan sistem, maka penelitian ini penting dilakukan. Hasil yang diharapkan adalah sistem IoT mampu menangkap data kebutuhan tanaman hidroponik melalui sensor. Disisi lain, model keamanan dengan teknik kriptografi dapat dilakukan pada proses input data dan informasi kebutuhan tanaman melalui platform android. Adapun perbedaan dari penelitian yang telah dilakukan oleh [15] dengan menggunakan DES yang hanya menampilkan hasil waktu enkripsi dekripsi tanpa mengetahui ketahanan terhadap keamanan data dalam IoT. Pada penelitian ini kami menguji ketahanan data menggunakan perhitungan entropy. Merujuk pada [16], maka kami akan menggunakan AES dalam melakukan proses enkripsi dekripsi untuk membuktikan keamanan IoT berbasis kriptografi.

\section{Metode Penelitian}

\subsection{Advanced Encryption Standard (AES)}

AES adalah algoritma simetris yang menggunakan kunci sama persis pada proses enkripsi dan dekripsi yang diimplementasikan dalam teknik tunggal atau gabungan seperti steganografi [18] atau kompresi data [19]. Berdasarkan panjang kunci yang digunakan, AES memiliki 3 jenis, yaitu AES 128 [8], AES 192 [20] dan AES 256 [21] sesuai Tabel 1.

Tabel 1. Versi AES Berdasarkan Panjang Kunci [22]

\begin{tabular}{llll}
\hline AES Version & $\begin{array}{l}\text { Key Length } \\
\text { (Nk Words) }\end{array}$ & $\begin{array}{l}\text { Block Size } \\
\text { (Nb Words) }\end{array}$ & $\begin{array}{l}\text { Number of } \\
\text { Rounds (Nb) }\end{array}$ \\
\hline AES -128 & 4 & 4 & 10 \\
AES -192 & 6 & 4 & 12 \\
AES -256 & 8 & 4 & 14 \\
\hline
\end{tabular}

Pada Tabel 1, setiap jenis menggunakan kunci internal yang berbeda dalam menjalankan kunci bulat untuk setiap putaran. Algoritma ini digunakan untuk mengenkripsi suatu dokumen dan file yang berisi teks dengan melakukan proses enkripsi secara paralel, umumnya beroperasi pada 128-bit atau 16 blok karakter. Blok 128-bit dalam teks biasa [23] dimasukkan ke dalam bentuk persegi berukuran $4 \times 4$ byte dengan operasi XOR kunci dan diproses sebanyak sepuluh kali 
menggunakan substitusi addkey linier untuk akan mengalami transformasi byte, setelah itu status menghasilkan ciphertext. AddRoundKey akan mengalami perubahan pada SubBytes, MixCloumns dan AddRoundKey secara

\subsection{Skema Penelitian} berulang sebanyak $\mathrm{Nr}$ (untuk AES-256 bit terdiri dari 14

Berdasarkan Gambar 1, skema penelitian loop). Proses putaran terakhir mengalami transformasi direpresentasikan menjadi dua bagian utama yaitu MixColoumns, sedangkan proses AddRoundKey enkripsi dan dekripsi. Dalam AES, proses enkripsi menggunakan perhitungan XOR menurut rumus 1 terdiri dari empat jenis operasi byte yaitu SubBytes, berikut [24].

ShiftBytes, ShiftRows, MixColoumns dan AddRoundKey.

Enkripsi awal di mulai dari status input yang kemudian $\mathrm{M}_{\mathrm{ij}}=\mathrm{X}_{\mathrm{ij}} \oplus \mathrm{Y}_{\mathrm{ij}}$

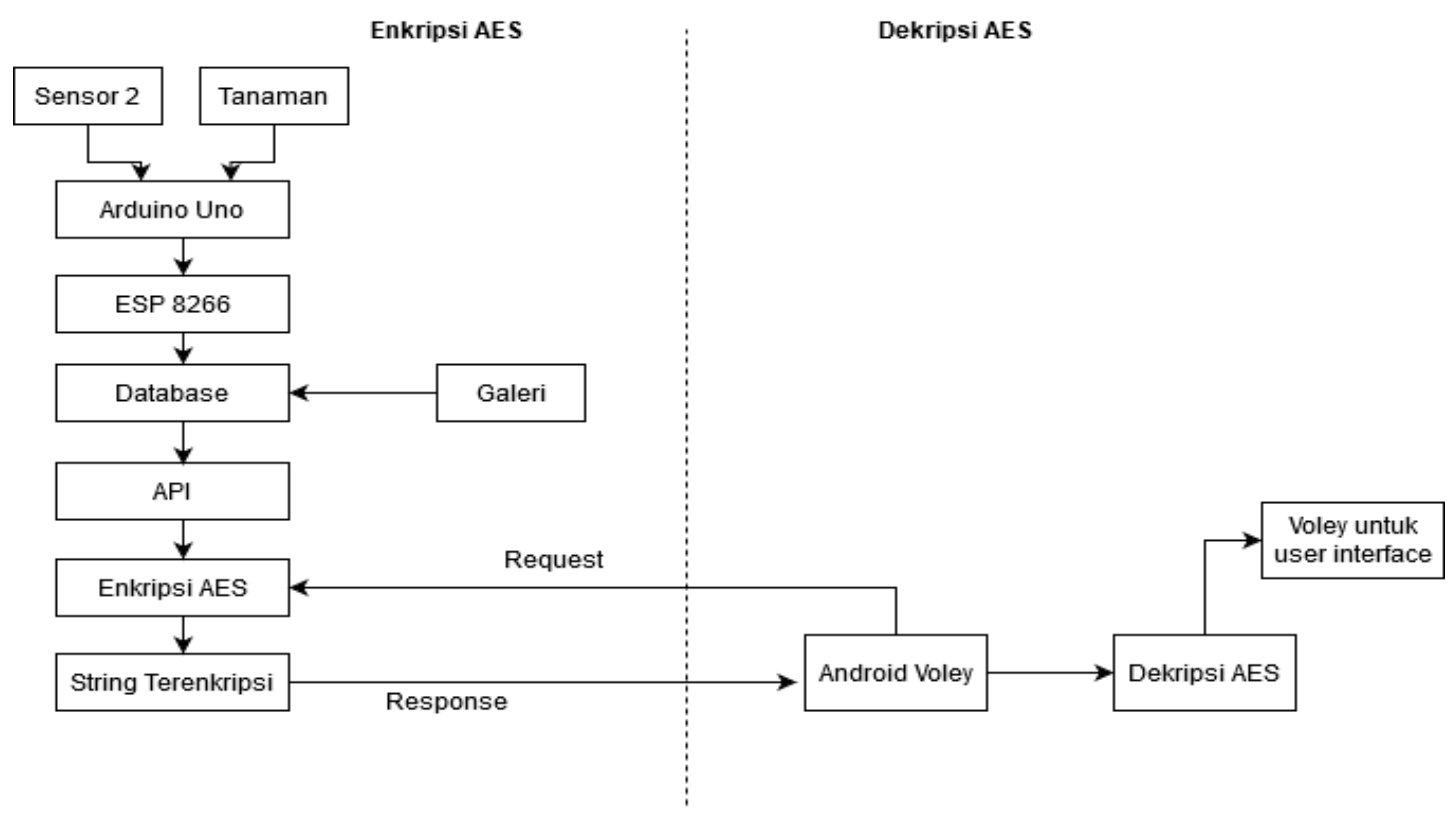

Gambar 1. Skema Penelitian

Pada proses dekripsi, luaran yang dihasilkan dengan seperti saat enkripsi, yaitu dengan mengoperasikan XOR menggunakan AES-128 berupa string dari putaran kunci. Hasil akhir luaran menggunakan voley library terakhir yang bersifat heksadesimal. Berdasarkan untuk mendapatkan akses dari API website. Kemudian Gambar 1, dekripsi hanya terjadi pada android data hasil proses dekripsi ini berupa string JSON dimana cipher text yang akan dikirim ke android saat android JSON ini berisi data yang diambil dari database yang meminta data terenkripsi dari server. Tahapan penelitian berguna untuk membantu menampilkan informasi yang keamanan sistem IoT tanaman menggunakan AES terdapat pada Android.

sesuai Gambar 1 dapat dijabarkan menjadi bebrapa

langkah sebagai berikut. Pertama proses inverse Add 2.3. Rancangan Sistem Hidroponik

Round Key, sama seperti selama enkripsi, dilakukan Mikrokontroler mengambil data tumbuhan hidroponik dengan mengoperasikan XOR. Kedua, inverse Mix yang telah diberi sensor, sehingga Arduino dapat Columns menggunakan metode yang hampir sama memperoleh data tentang kebutuhan tumbuhan. dengan Mix Columns pada saat enkripsi. Perbedaannya Selanjutnya data tersebut diolah menggunakan ESP adalah yang digunakan $a(x)$ yaitu invers (a-1). 8266. ESP 8266 on Chip System (SoC) untuk mengolah Selanjutnya pada langkah ketiga, inverse Shift Row data yang telah diambil oleh Arduino, sehingga data merupakan kebalikan dari proses enkripsi ShiftRows, tersebut dapat di kirim ke database. Database adalah jika pada saat enkripsi dilakukan proses dari atas dengan data yang telah dikelompokkan dalam satu memori baris kedua bergeser 1 byte, baris 3 bergeser 2 byte, baris tertentu berisi data yang saling berhubungan. Data 4 bergeser 3 byte. Pada proses dekripsi, baris 4 bergeser tersebut berfungsi mempermudah akses 1 byte, baris ke 3 bergeser 2 byte dan baris 2 bergeser 3 terkomputerisasi dalam perawatan tumbuhan hidroponik byte. Langkah ke empat yaitu inverse Sub Byte yang berbasis IoT. Secara realtime, data tanaman telah memiliki cara kerja yang sama dengan Sub Bytes saat tertanam pada Sensor2 dan tersimpan di Galeri. Data melakukan enkripsi. Perbedaannya terletak pada S-Box pada Sensor2 terdiri dari suhu, jarak, Potensi Hidrogen yang digunakan saat mengubah state yang harus diganti. (PH), dan Total Dissolve Solid (TDS) yang merupakan Langkah ke lima yaitu inverse Add Round Key. Sama padatan terlarut dalam air. Pada Galeri, terdapat

Jurnal RESTI (Rekayasa Sistem dan Teknologi Informasi) Vol. 4 No. 6 (2020) 1157 - 1164 
kumpulan gambar realtime perkembangan tanaman Application Programming Interface (API) digunakan hidroponik. Gambar yang dihasilkan akan di kirim ke untuk melakukan integrasi data dari database. database dan akan di hapus secara berkala selama seminggu dengan tujuan mengurangi penumpukan data dalam database. Jenis tanaman dan tempat serta spesifikasinya (model hidroponik horizontal dan model

Pada Gambar 2 dapat dilihat rancangan sistem yang telah diimplementasikan. Gambar 2 (a) merupakan activity diagram. Pada activity diagram digambarkan

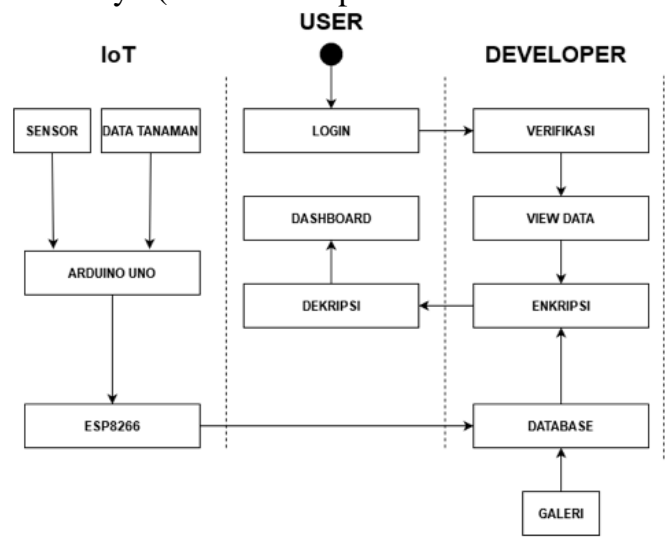

(a) Activity Diagram

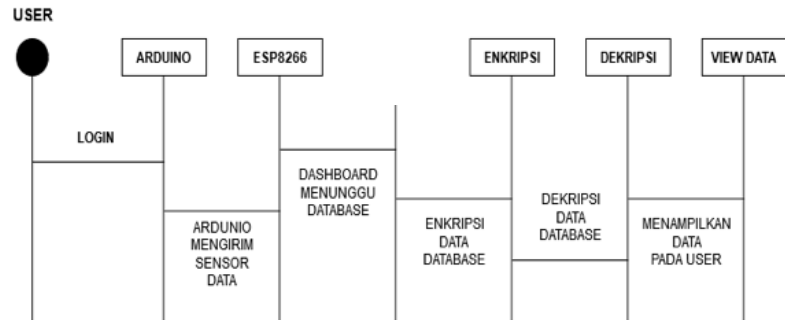

(b) Sequence Diagram

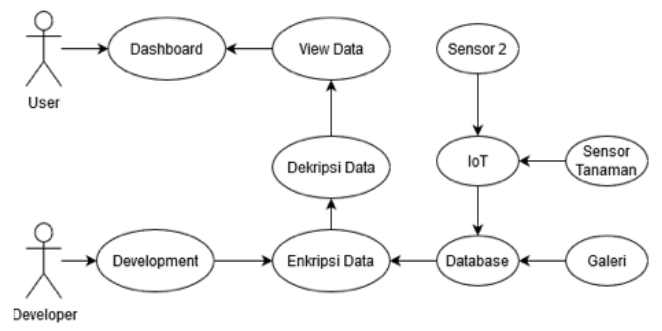

(c) Use Case

Gambar 2. Rancangan Sistem Kriptografi Hidroponik

vertikal) digunakan sebagai input data. Database harus bahwa user memerlukan login melalui dashboard. dapat dibaca oleh android sehingga diperlukan Proses pencocokan user menggunakan arduino uno. Selanjutnya, sistem akan memproses data dari database.

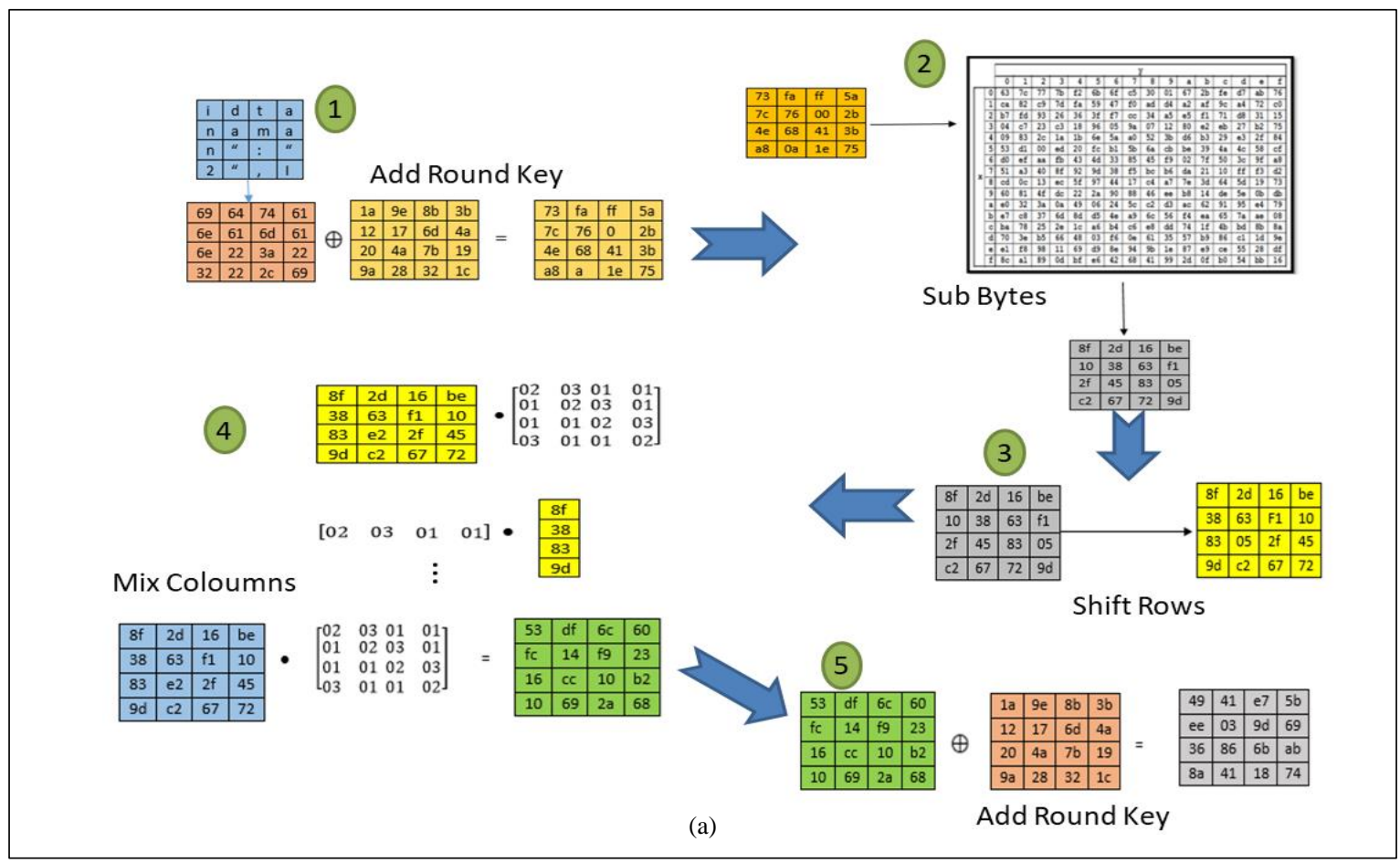

Jurnal RESTI (Rekayasa Sistem dan Teknologi Informasi) Vol. 4 No. 6 (2020) 1157 - 1164 


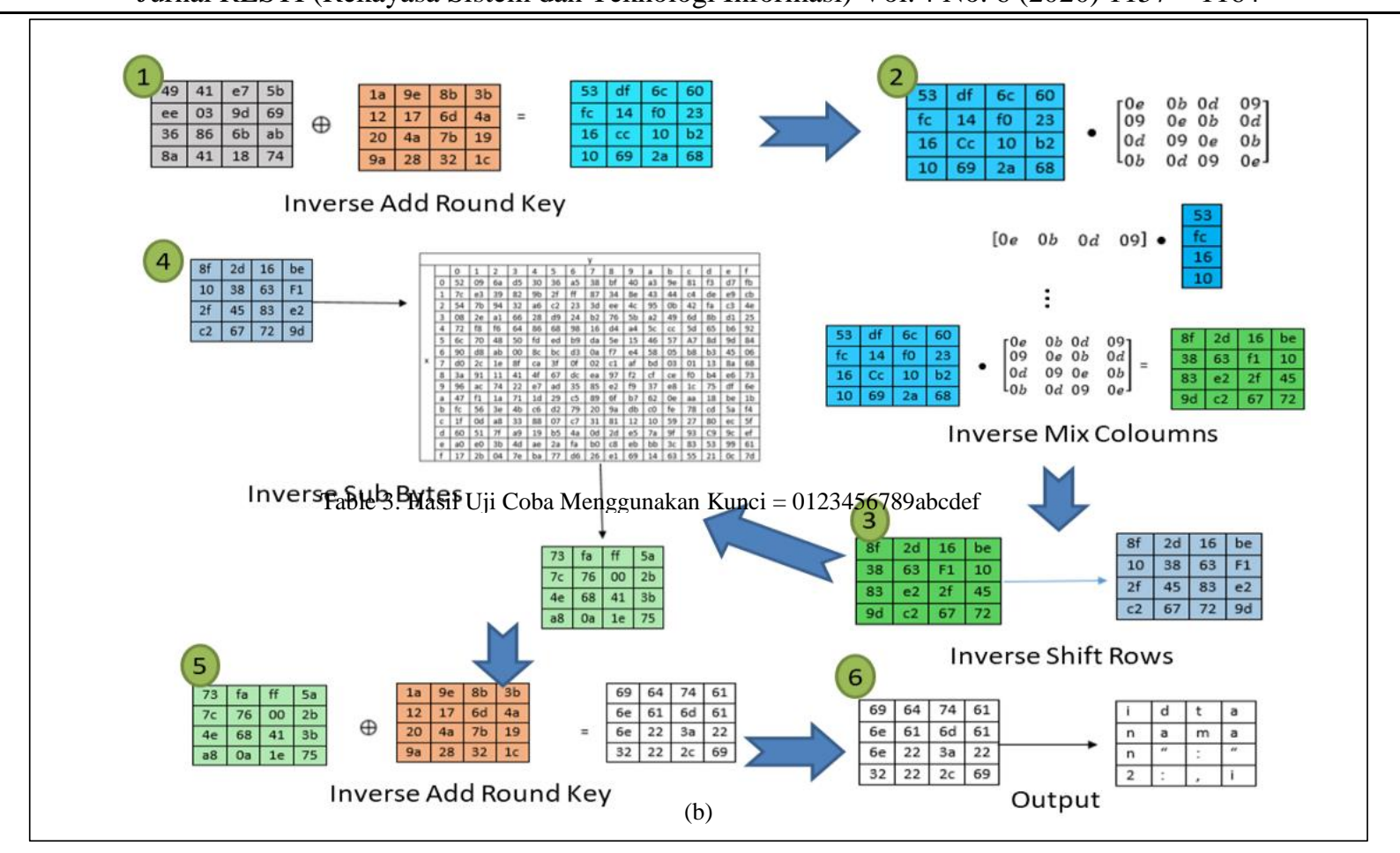

Gambar 3. Perhitungan manual (a) enkripsi, (b) dekripsi

Proses enkripsi dan dekripsi menggunakan kunci yang kebutuhan tanaman hidroponik yang ditanam yaitu suhu sama dan dilakukan secara realtime. Pada Gambar 2 (b), air, jarak tanam, Potensial Hidrogen (PH) dan Total terdapat sequence diagram yang menggambarkan alur Dissolve Solid (TDS). Sensor tanaman berisi model atau Arduino dalam mengoleksi data dari sensor, kemudian penataan tanaman hidroponik yang dilakukan baik dikirim ke ESP8266 sehingga data bisa di upload ke secara verikal maupun horizontal. Sedangkan pada database. Sebelum data dikirimkan kepada user, data galeri berisi gambar tentang kesehatan tanaman telah melewati proses enkripsi dengan kunci tertentu. hidroponik yang ditanam. Semua data diambil melalui Ketika user mengambil data, proses dekripsi secara database web Udinus Hydroponic IoT berupa JSON realtime terjadi. Gambar 2 (c) adalah use case dari yang akan dienkripsi dalam bentuk API bertipe data aplikasi IoT hidroponik berbasis kriptografi AES. string. Gambaran mengenai parameter dalam Pemakai dan pengembang aplikasi saling berinteraksi implementasi sistem dapat dilihat pada Gambar 3.

dalam proses pengambilan data hingga proses pemantauan kebutuhan tanaman hidroponik dapat selesai dilakukan dengan baik.

2.3. Proses Enkripsi dan DekripsDalam penelitian ini, perhitungan manual AES telah di uji coba untuk pengecekan terhadap hasil kriptografi sesuai Gambar 3. Pada Gambar 3, dijelaskan bahwa kunci yang digunakan untuk proses enkripsi dekripsi hingga dihasilkan sebuah ciphertext. Pada Gambar 3, terdapat proses perhitungan kunci awal yang dihitung menggunakan sejumlah putaran. Kunci awal berupa bilangan heksadesimal seperti kunci yang digunkaan pada Tabel 3. Proses perhitungan sub bytes menggunakan bantuan sub box yang digunakan untuk mencari perpotongan antara nilai pada kedua bilangan heksadesimal.

\section{Hasil dan Pembahasan}

\subsection{Pengumpulan Data}

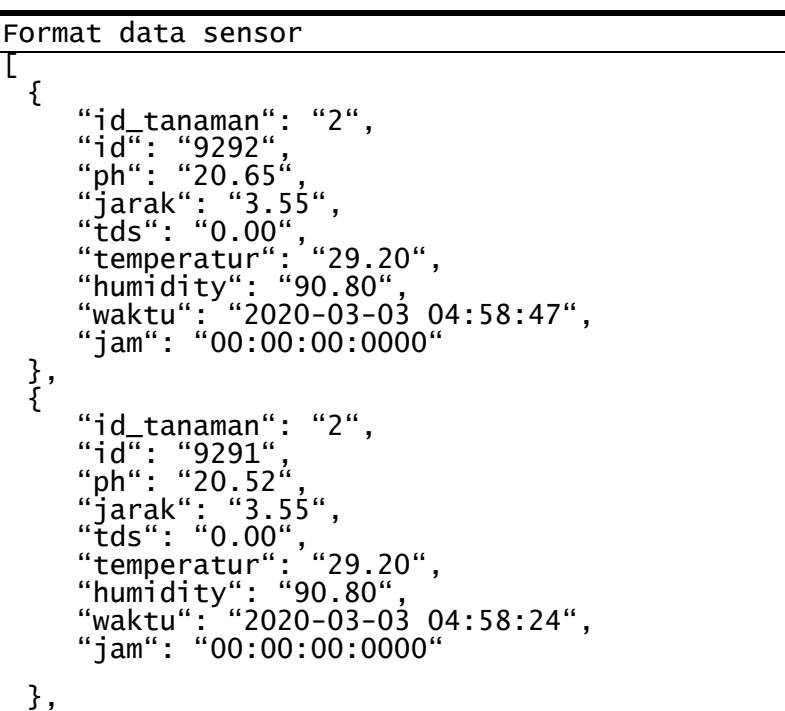

Data yang dienkripsi dan didekripsi diambil merdasarkan parameter pada format data di atas, data subsistem Sensor2, tanaman dan galeri. Pada Sensor2 enkripsi-dekripsi. Dalam penelitian ini digunakan 100 ditangkap informasi yang berisi data mengenai buah tanaman kangkung. Terdapat keterangan mengenai 
jarak, ph, id tanaman, tds, temperatur, humidity, waktu dan jam pengambilan data.

\subsection{Analisis Keamanan Data} dilakukan dengan menghitung beberapa alat uji yaitu dengan melihat rasio antara jumlah bit ciphertext [25] Avalanche Effect (AE) sesuai rumus (2), Entropy sesuai karena adanya perubahan plaintext pada jumlah bit [26]. rumus (3), dan hasil enkripsi dekripsi berupa teks asli Jika konversi bit adalah setengah dari jumlah bit di dari sistem yang telah di buat.

$$
A E=\frac{\text { bit yang berubah }}{\text { total bit }} \times 100 \%
$$

Tabel 2. Hasil AE dan Entropi

\begin{tabular}{lll}
\hline Contoh Pesan & AE & Entropi \\
\hline Hydroponic Plant & $56.21 \%$ & 6.2120 \\
Kale Plant & $57.12 \%$ & 6.3128
\end{tabular}

\begin{tabular}{lll} 
Android System Hydroponic & $50.37 \%$ & 6.1470 \\
Sensor IoT esp8266 & $52.88 \%$ & 6.3566 \\
Kale Testing Equipment & $58.01 \%$ & 6.4521 \\
\hline
\end{tabular}

AE adalah metode untuk mengetahui berapa persen ciphertexts atau 50\%, maka algoritma telah memenuhi proses enkripsi dan dekripsi yang benar [27]. Pada Tabel 2, dipaparkan perolehan nilai AE dan entropy. Pada Tabel 2 dapat dilihat bahwa pesan yang digunakan dalam percobaan tidak hanya satu. Terdapat lima pesan yang digunakan untuk lima buah proses berbeda dengan tujuan untuk membandingkan nilai AE dan entropy saja.

Table 3. Hasil Uji Coba Menggunakan Kunci = 0123456789abcdef

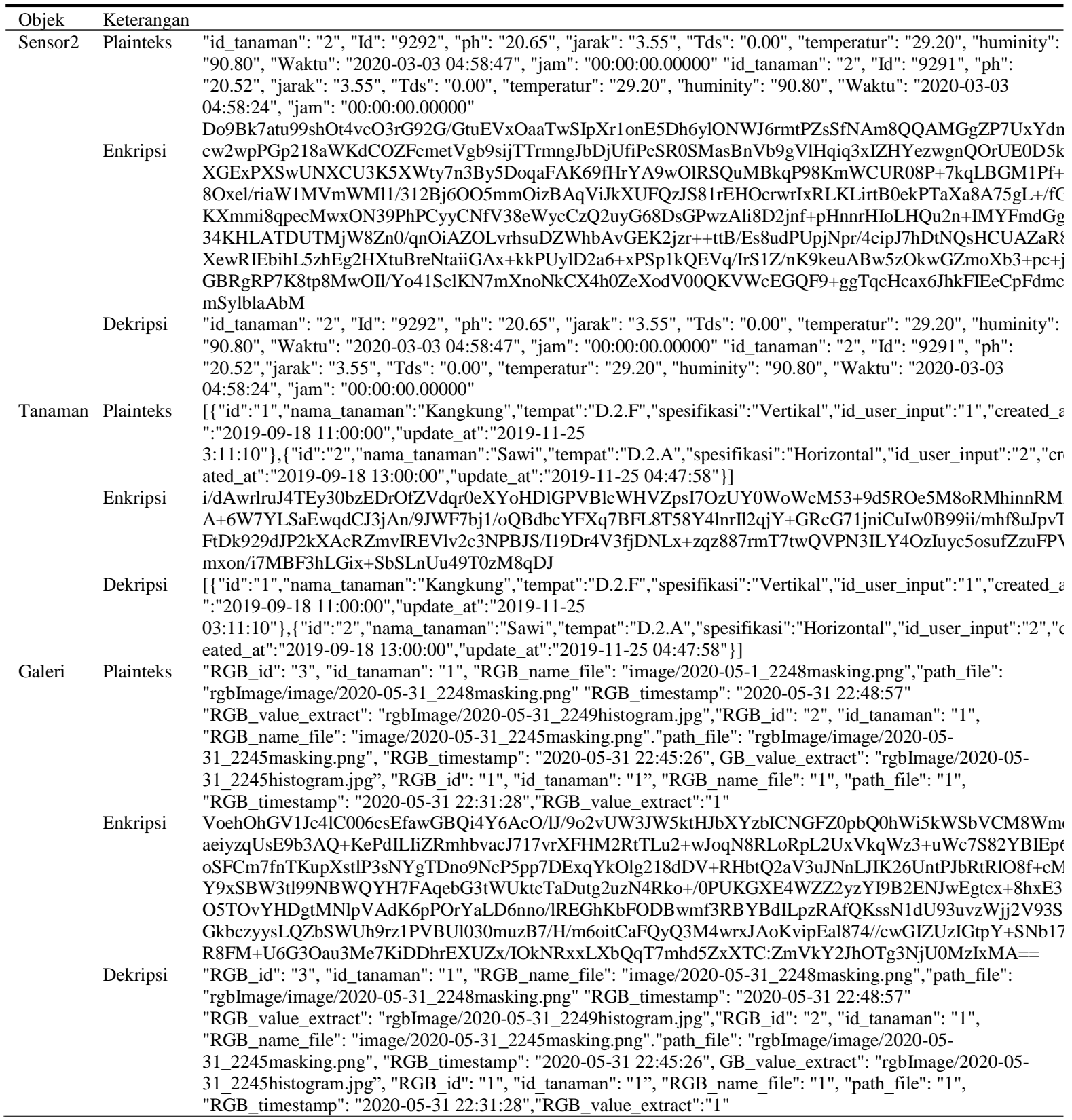

Jurnal RESTI (Rekayasa Sistem dan Teknologi Informasi) Vol. 4 No. 6 (2020) 1157 - 1164 
Setiap proses enkripsi dekripsi IoT android dilakukan dalam rentang waktu yang lebih lama. Penelitian menggunakan sebuah kunci yang sama. Seluruh data uji selanjutnya juga dapat dilakukan dengan coba menghasilkan $\mathrm{AE}$ di atas 50\%, di mana $\mathrm{AE}$ menggabungkan AES dan algoritma transposisi untuk terendah yaitu $50,37 \%$ dan tertingi 58,01\%. Nilai melakukan teknik super enkripsi dengan tujuan entropy seluruh data uji coba .atas enam dengan nilai peningkatan keamanan data.

tertinggi yaitu 6.4521. Tetapi pada penelitian ini belum dicapai entropy sempurna mendekati nilai 8. Alat uji lain Ucapan Terimakasih

yang digunakan adalah entropy. Eksperimen dengan entropy menunjukkan hasil mendekati nilai tertinggi. Metode ini memiliki ukuran ruang kunci $\mathrm{K}$ di mana nilai entropy terbaik adalah 8 [30]. Semakin besar nilai entropy [31], maka semakin sulit memecahkan ciphertext. Perhitungan entropy dapat dilakukan dengan rumus (3).

$$
H(X)=\sum_{i=0}^{n} a_{i}{ }^{2} \log \left(p\left(S_{i}\right)\right)
$$

Menurut rumus 3, $X$ adalah pesan, $S i$ adalah simbol pada pesan, $p\left(S_{i}\right)$ adalah peluang terjadinya $S_{i}$ dan $a_{i}$ adalah banyaknya kemunculan $S_{i}$.

Alat uji ketiga yaitu Bit Error Ratio (BER). BER digunakan untuk menghitung jumlah perbedaan bit pada teks dekripsi dengan plaintext asli. Dalam penelitian ini dihasilkan nilai BER $=0$. Berdasarkan [32], nlai 0 menunjukkan bahwa tidak terdapat kesalahan dalam proses dekripsi dan teks dekripsi sama persis dengan dengan teks asli. Pada Tabel 3, pengujian menggunakan teks asli dari database telah diuji coba. Berdasarkan tabel tersebut dapat dibandingkan plaintext dan teks hasil dekripsi. Seluruh data dari sampel tool Sensor2, tanaman dan Galeri menghasilkan tampilan plaintext dan teks dekripsi yang sama persis.

\section{Kesimpulan}

Berdasarkan hasil pengujian sistem enkripsi yang diimplementasikan pada aplikasi hidroponik menggunakan algoritma 128-bit Advanced Encryption Standard (AES), dapat disimpulkan bahwa algoritma AES cocok untuk diterapkan dalam mengamankan data yang terdapat pada sistem/database. Proses enkripsi dilakukan untuk menghasilkan data yang tidak mudah dibaca dan tidak mudah diretas oleh orang lain kecuali mereka memiliki kunci untuk mendekripsi data tersebut. Kunci yang digunakan untuk mengenkripsi dan mendekripsi sama. Jika kunci yang digunakan sama maka data dapat digunakan, tetapi jika berbeda maka hasilnya tidak akan terbaca. Pada penelitian ini, telah dilakukan uji coba dan evaluasi Advanced Encryption Standard (AES). Algoritma tersebut dapat bekerja secara lintas platform yaitu menyembunyikan data pada saat proses pengiriman dari server ke Android dengan benar dan aman. Berdasarkan penelitian yang telah dilakukan, terdapat hasil yang kurang maksimal yaitu nilai entropy yang belum sempurna yaitu masih berkisar pada angka 6.1 sampai 6.4 dan diharapkan dapat menghasilkan nilai sempurna yaitu 8. Pada penelitian selanjutnya diharapkan nilai pengujian dapat optimal dengan menggunakan algoritma simetris atau asimetris lain. Jumlah data yang lebih banyak dan pengukuran hasil

Penelitian ini terselenggara atas bantuan Universitas Dian Nuswantoro dalam memberikan kesempatan pada penulis untuk menggunakan Laboratorium Rekayasa Perangkat Lunak dan Database (RPLD) khususnya dalam pengembangan metode tepat guna IoT Tanaman Kangkung.

\section{Ucapan Terimakasih}

Penelitian ini terselenggara atas bantuan Universitas Dian Nuswantoro dalam memberikan kesempatan pada penulis untuk menggunakan Laboratorium Rekayasa Perangkat Lunak dan Database (RPLD) khususnya dalam pengembangan metode tepat guna IoT Tanaman Kangkung.

\section{Daftar Rujukan}

[1] Winder Davey. (2019, July) Confirmed: 2 Billion Records Exposed In Massive Smart Home Device Breach. [Online]. https://www.forbes.com/sites/daveywinder/2019/07/02/confirmed2-billion-records-exposed-in-massive-smart-home-devicebreach/\#230e8b36411c

[2] Saurabh Singh, Pradip Kumar Sharma, Seo Yeon Moon, and Jong Hyuk Park, "Advanced lightweight encryption algorithms for IoT devices: survey, challenges and solutions," Journal of Ambient Intelligence and Humanized Computing, 2017.

[3] Sarada Prasad Gochhayat et al., "Reliable and Secure Data Transfer in IoT Networks," Wireless Networks : The Journal of Mobile Communication, Computation and Information, 2019.

[4] Sana Belguith, Nesrine Kaaniche, Maryline Laurent, Abderrazak Jemai, and Rabah Attia, "PHOABE: Securely outsourcing multiauthority attribute based encryption with policy hidden for cloud assisted IoT," Computer Networks Vol 133, Issue 14, pp. 141-156, 2018

[5] Xinlei Wang, Jianqing Zhang, Eve M. Schooler, and Mihaela Ion, "Performance evaluation of Attribute-Based Encryption: Toward data privacy in the IoT," in IEEE International Conference on Communications (ICC), Sydney, NSW, Australia, 2014.

[6] Kun Lin Tsai et al., "AES-128 Based Secure Low Power Communication for LoRaWAN IoT Environments," IEEE Access Vol 6, Topic: Security and Trusted Computing for Industrial Internet of Things, pp. 45325-45334, 2018.

[7] Ritambhara, Alka Gupta, and Manjit Jaiswal, "An enhanced AES algorithm using cascading method on 400 bits key size used in enhancing the safety of next generation internet of things (IOT)," in International Conference on Computing, Communication and Automation (ICCCA), Greater Noida, India, 2017.

[8] Ali Akbar Pammu, Kwen-Siong Chong, Weng-Geng Ho, and BahHwee Gwee, "Interceptive side channel attack on AES-128 wireless communications for IoT applications," in IEEE Asia Pacific Conference on Circuits and Systems (APCCAS), Jeju, South Korea, 2016.

[9] Weize Yu and Selcuk Kose, "A Lightweight Masked AES Implementation for Securing IoT Against CPA Attacks," IEEE Transactions on Circuits and Systems I: Regular Papers (Volume: 64 , Issue: 11), 2017. 
[10] Noveline Aziz Fauziah, Eko Hari Rachmawanto, De Rosal Ignatius Moses Setiadi, and Christy Atika Sari, "Design and Implementation of AES and SHA-256 Cryptography for Securing Multimedia File over Android Chat Application," in International Seminar on Research of Information Technology and Intelligent Systems (ISRITI), Yogyakarta, Indonesia, 2018, pp. 146-151.

[11] B.K.S. Rajaram and Krishna Prakash N, "Secure MQTT using AES for Smart Homes in IoT Network," International Journal of Innovative Technology and Exploring Engineering (IJITEE), pp. 483-485, 2019.

[12] Turki Ali Alghamdi, Ishtiaq Ali, Nadeem Javaid, and Muhammad Shafiq, "Secure service provisioning scheme for lightweight IoT devices with a fair payment system and an incentive mechanism based on blockchain," IEEE Access Vol 8, pp. 1048-1061, 2019.

[13] Wiwin Styorini and Dwi Harinitha, "Analisis Performansi Algoritma AES dan Blowfish Pada Aplikasi Kriptografi," in Seminar Nasional, pp. 1-6.

[14] Aji Fitrah Marisman and Anita Hidayati, "PEMBANGUNAN APLIKASI PEMBANDING KRIPTOGRAFI DENGAN CAESAR CIPHER DAN ADVANCE ENCRYPTION STANDARD," Jurnal Penelitian Komunikasi dan Opini Publik, vol. 19, no. 3, pp. 213-222, Desember 2015.

[15] Fernando Fernando and Lukas Lukas, "IMPLEMENTASI DAN ANALISIS LIGHTWEIGHT CRYPTOGRAPHY UNTUK INTERNET OF THINGS (IOT)," JURNAL ELEKTRO, vol. 10, no. 2, pp. 85-94, Oktober 2017.

[16] Resianta Perangin-angin, Indra Kelana Jaya, Benget Rumahorbo, and Berlian Juni R. Marpaung, "Analisa Alokasi Memori dan Kecepatan Kriptograpi Simetris Dalam Enkripsi dan Dekripsi," INFORMATION SYSTEM DEVELOPMENT [ISD], vol. 4, no. 1, pp. 11-16, Januari 2019.

[17] Duy-Hieu Bui, Diego Puschini, Simone Bacles-Min, Edith Beigné, and Xuan-Tu Tran, "Ultra low-power and low-energy 32-bit datapath AES architecture for IoT applications," in International Conference on IC Design and Technology (ICICDT), Ho Chi Minh City, Vietnam, 2016, pp. 1-4.

[18] Eko Hari Rachmawanto, Khabib Prasetyo, Christy Atika Sari, De Rosal Ignatius Moses Setiadi, and Nova Rijati, "Secured PVD Video Steganography Method based on AES and Linear Congruential Generator," in International Seminar on Research of Information Technology and Intelligent Systems (ISRITI), Yogyakarta, Indonesia, 2018, pp. 163-167).

[19] Mutia Rizky Ashila, Nur Atikah, De Rosal Ignatius Moses Setiadi, ${ }^{[31]}$ Eko Hari Rachmawanto, and Christy Atika Sari, "Hybrid AESHuffman Coding for Secure Lossless Transmission," in Fourth International Conference on Informatics and Computing (ICIC),[3 Semarang, Indonesia, 2019.

[20] Ioannis Georgiadis, Michael Dossis, and Sotirios Kontogiannis, "Performance evaluation on IoT devices secure data delivery processes," in Proceedings of the 22nd Pan-Hellenic Conference on Informatics, Athens, Greece, 2018, pp. 306-311.

1] Alex Biryukov, Dmitry Khovratovich, and Ivica Nikolić, "Distinguisher and Related-Key Attack on the Full AES-256," in Advances in Cryptology - CRYPTO 2009. Lecture Notes in Computer Science, vol 5677. Berlin, Heidelberg: Springer, 2009, pp. 231-249.

2] Alex Biryukov, Orr Dunkelman, Nathan Keller, Dmitry Khovratovich, and Adi Shamir, "Key recovery attacks of practical complexity on AES-256 variants with up to 10 rounds," in nternational Conference on the Theory and Applications of Cryptographic Techniques, Berlin, Heidelberg., 2010, pp. 299-319.

23] Bawna Bhat, Abdul Wahid Ali, and Apurva Gupta, "DES and AES performance evaluation," in International Conference on Computing, Communication \& Automation, Noida, India, 2015, pp. 887-890.

[24] Simon Heron, "Advanced Encryption Standard (AES)," Network Security Vol 2009 Issue 12, pp. 8-12, 2010.

5] Ibnu Utomo Wahyu Mulyono, Ajib Susanto, Muhamad Rizky Fajar Febrian, and Ghaitsa Ardelia Rosyida, "A Combination of Hill Cipher and LSB for Image Security," Scientific Journal of Informatics, Vol. 7, No. 1, pp. 155-165, 2020.

26] Amish Kumar and Namita Tiwari, "Effective Implementation and Avalanche Effect of AES," International Journal of Security, Privacy and Trust Management (IJSPTM), Vol. 1, No 3/4, pp. 3135, 2012.

27] Sriram Ramanujam and Marimuthu Karuppiah, "Designing an algorithm with high Avalanche Effect," IJCSNS International Journal of Computer Science and Network Security, VOL.11 No.1, pp. 106-111, 2011.

28] Rotem Arnon-Friedman, Frédéric Dupuis, Omar Fawzi, Renato Renner, and Thomas Vidick, "Practical device-independent quantum cryptography via entropy accumulation," Nature Communications, pp. 1-11, 2018.

[29] Bobby Jasuja and Abhishek Pandya, "Crypto-Compression System: An Integrated Approach," International Journal of Computer Applications, Vol 116, No 21, pp. 34-41, 2015.

0] Amandeep Singh, Praveen Agarwal, and Mehar Chand, "Image Encryption and Analysis using Dynamic AES," in 5th International Conference on Optimization and Applications (ICOA), Kenitra, Morocco, 2019, pp. 1-6.

1] Georgios Makris and Ioannis Antoniou, "Chaos Cryptography with prescribed Entropy Production," in International Electronic Conference on Entropy and Its Applications, 2015, pp. 1-17.

] O. Shoewu and Segun O. Olatinwo, "Securing Text Messages using Elliptic Curve Cryptography and Orthogonal," The Pacific Journal of Science and Technology, Volume 14. Number 2, pp. 220-227, 2013. 